\title{
AP4 Transcription Factor Binding Site is a Repressor Element in $e k 2$ Promoter of Human Liver Carcinoma Cell Line, HepG2
}

(Tapak Pengikat Faktor Transkripsi AP4 adalah Unsur Penindas dalam Promoter ek2 Titisan Sel Karsinoma Hati Manusia, HepG2)

\section{Zhi Hui Teh, Chee Sian Kuan, Boon Huat Lim, Wei Cun See ToO \& Ling Ling FeW*}

\begin{abstract}
Ethanolamine kinase (EK) is the first enzyme in the Kennedy pathway for the biosynthesis of phosphatidylethanolamine. Although EK has been reported to be involved in phospholipid biosynthesis, carcinogenesis, cell growth, muscle development and sex determination during embryonic development, little is known about its transcriptional regulation by endogenous or exogenous signals. Human EK exists as EK1, EK $2 \alpha$ and EK $2 \beta$ isoforms, encoded by two separate genes, named ek1 and ek2. Compared to ek1 gene, ek2 is expressed at a higher level in liver and EK2 isoforms also accept choline as substrate besides ethanolamine, which could contribute to liver carcinogenesis. The main aim of this study was to analyze and characterize the human ek2 promoter in cultured mammalian cells. Human ek2 (2011 bp) promoter was cloned into reporter vector, pGL4.10 [luc2] and the promoter activities were studied in human liver carcinoma (HepG2 cells). Sequence analyses showed that ek2 promoter contains numerous putative transcription factor binding sites including AP4 and it is devoid of a recognizable consensus TATA box but it contains a high number of guanine $(G)$ and cytosine $(C)$ nucleotides. PCR mutagenesis of three nucleotides at E-box motif of AP4 transcription binding site located between -293 and -276 of ek2 promoter was successfully performed to show that AP4 transcription factor binding site acts as a repressive element in the regulation of $\mathrm{ek} 2$ expression. AP4 upregulation has been implicated in bad prognosis of carcinoma, therefore the regulatory role of AP4 binding site reported in this study could be a link between ek 2 and carcinogenesis. Although further studies need to be carried out to understand and to determine the repression mechanism of AP4 in ek2 promoter, the characterization and analysis of ek promoter performed in this study provide important understanding of its basal transcriptional regulation which would allow us to control ek expression levels in pathologic conditions that involve this gene.
\end{abstract}

Keywords: AP4; ethanolamine kinase; Hep G2; promoter; transcription factor

\section{ABSTRAK}

Etanolamina kinase (EK) merupakan enzim pertama dalam laluan Kennedy untuk biosintesis fosfatidiletanolamina. Walaupun EK telah dilaporkan terlibat dalam biosintesis fosfolipid, karsinogenesis, pertumbuhan sel, perkembangan otot dan penentuan jantina semasa pertumbuhan embrio, maklumat tentang kawalan transkripsi EKoleh rangsangan dalaman atau luaran masih tidak jelas sehingga kini. EK manusia wujud sebagai isoform EKl, EK2 $\alpha$ dan EK2 $\beta$ yang dikodkan oleh dua gen berasingan iaitu ek1 dan ek2. Berbanding dengan gen ek1, ek2 diekspres pada tahap yang lebih tinggi di dalam hati dan isoform EK2 juga menerima kolina sebagai substrat selain daripada etanolamina justeru menyumbang kepada karsinogenesis hati. Tujuan utama kajian ini adalah untuk menganalisis dan mencirikan promoter ek2 dalam sel mamalia. Promoter ek2 (2011 bp) manusia telah diklonkan ke dalam vektor pelapor pGL4.10 [luc2] dan dikaji dalam sel karsinoma hati manusia (HepG2). Analisis jujukan menunjukkan bahawa terdapat banyak tapak perlekatan bagi faktor transkripsi termasuk AP4 pada promoter ek2. Kajian ini juga menunjukkan tiada kehadiran kotak TATA yang boleh dikenali tetapi mengandungi nukleotida guanina $(G)$ dan sistina $(C)$ yang banyak. Mutagenesis PCR tiga nukleotida pada motif E-box dalam tapak perlekatan faktor transkripsi AP4 yang terletak antara -276 hingga -293 pada promoter ek2 telah berjaya dilakukan untuk menunjukkan tapak perlekatan faktor transkripsi AP4 berperanan sebagai unsur penindas dalam pengawalan pengekspresan ek2. Peningkatan aras AP4 telah dikaitkan dengan prognosis buruk karsinoma. Oleh itu, peranan pengawalaturan tapak perlekatan AP4 yang dilaporkan dalam kajian ini mungkin menghubungkaitkan ek2 dengan karsinogenesis. Walau pun kajian lanjut perlu dijalankan untuk memahami dan menentukan mekanisme penindasan AP4 dalam promoter ek2, namun pencirian dan analisis promoter ek2 yang dilakukan dalam kajian ini memberikan pengetahuan penting mengenai kawalan asas transkripsi ek2 yang dapat membantu pengawalan aras pengekspresan ek dalam keadaan patologi yang melibatkan gen ini.

Kata kunci: AP4; etanolamina kinase; faktor transkripsi; HepG2; promoter 


\section{INTRODUCTION}

Phosphatidylethanolamine (PtdEtn) is the most abundant phospholipid in the mammalian cell membrane after phosphatidylcholine (PtdCho), where it makes up 20 to $50 \%$ of total phospholipids. At the cellular level, more than $80 \%$ of PtdEtn are located within the inner leaflet of the cell membrane (Vance 2008). The majority of PtdEtn is synthesized via the CDP-ethanolamine pathway and phosphatidylserine decarboxylation pathway (Bleijerveld et al. 2007). In the CDP-ethanolamine pathway, ethanolamine is converted to PtdEtn by the sequential actions of ethanolamine kinase (EK), CTP: phosphoethanolamine cytidylyltransferase and finally choline/ethanolaminephosphotransferase. Ethanolamine kinase (EC 2.7.1.82) is the first enzyme in the CDPethanolamine pathway. It consists of two isoforms, EK 1 and EK2 ( $\alpha$ and $\beta$ ), encoded by $e k 1$ and $e k 2$ genes, respectively (Lykidis et al. 2001). Elevated EK activity induced by oncogenes and carcinogens has been shown to correlate with cell growth and survival that leads to carcinogenesis (Kiss 1999; Kuan et al. 2016).

EK2 was found to be expressed at a higher level compared to EK1 in liver and reproductive tissues of humans (Lykidis et al. 2001). In situations when choline is deficient, EK2 is important in supplying PtdEtn to prevent liver malfunction (Tian et al. 2006; Walkey et al. 1998). EK2 was reported to be involved in testicular maturation as suggested by its pattern of expression in developing mouse testes (Hurley et al. 2004). Studies showed that EK1 had no activity towards choline and neither was it inhibited by choline whereas EK2 accepted choline as substrate and choline competed with ethanolamine during catalysis (Lykidis et al. 2001; Spanner \& Ansell 1978). These studies therefore proved that EK1 and EK2 are indeed different, despite their similarities in sequence. Ek2 knocked out mice did not affect liver phospholipid metabolism, neural development, or testicular function but instead, have major effects on maternal-specific failure to support late embryonic development because of the development of placental thrombosis, which resulted in $33 \%$ reduced litter size (Tian et al. 2006).

A promoter is a region of DNA that initiates transcription of a particular gene. Promoters contain specific DNA sequences such as response elements that provide for binding of transcription factors. These transcription factors have specific DNA binding motif that recognize the corresponding nucleotides on the promoters to regulate gene expression. Previously, we showed that trichostatin A, a histone deacetylase inhibitor, could increase the expression of $e k 2$ in HepG 2 cells possibly by modulating the binding of transcription factors to the promoter region of this gene (Chua et al. 2015). Therefore, this study used the same cell line to investigate the role of activating enhancer binding protein 4 (AP4) cis acting element in human $e k 2$ promoter. AP4 has the ability to control cell signal transduction, growth, development and apoptosis by binding to AP4 sites on promoters of various genes such as angiotensinogen, APH-1A, Caspase-9, PAHX-AP1, proenkephalin and E7 oncoprotein genes. AP4 upregulation has also been suggested as an indicator of bad prognosis in carcinoma cells (Liu et al. 2012). In this study we found that AP4 repressed $e k 2$ promoter activity. Mutation of AP4 element significantly increased the $e k 2$ promoter activity.

\section{MATERIALS AND METHODS}

\section{COMPUTATIONAL ANALYSIS OF EK2 PROMOTER SEQUENCE}

The 5' upstream region (putative promoter region) of ek2 gene was retrieved by combining the information from NCBI (http://www.ncbi.nlm.nih.gov/) database and BLAT server (Kent 2002). The GenBank accession numbers for human $e k 2$ transcript was NM_018208. The putative promoter region of $e k 22000 \mathrm{bp}$ upstream of the ATG translation start codon was analyzed by TFSEARCH (Heinemeyer et al. 1998) and MatInspector 8.0 (Quandt et al. 1995) to identify the putative transcription factor binding sites. The minimum threshold score was set at 85.0 for TFSEARCH. The thresholds for matrix similarity and core similarity were set at 0.90 and 0.85 , respectively, for MatInspector 8.0.

\section{CELL CULTURE}

Hepatocellular carcinoma cell line, HepG2 (ATCC no. HB-8065) was cultured and maintained in high glucose Dulbecco's modified Eagle's medium (DMEM) supplemented with $10 \%(\mathrm{v} / \mathrm{v})$ heat inactivated fetal bovine serum (FBS), $100 \mathrm{U} / \mathrm{mL}$ penicillin and $100 \mu \mathrm{g} /$ $\mathrm{mL}$ streptomycin. The cells were incubated in the $37^{\circ} \mathrm{C}$ incubator with $5 \% \mathrm{CO}_{2}$ and $95 \%$ humidity.

\section{CLONING AND MUTATION OF EK2 PROMOTER}

Forward primer ( $e k 2-2000-5$ ') and reverse primer (ek2-3') (Table 1) were used to amplify $e k 2$ promoter from human genomic DNA (Roche, Germany). XhoI (5') and HindIII (3') were introduced into the primers for the purpose of cloning. The promoter fragment was cloned by PCR amplification in a $50 \mu \mathrm{L}$ reaction mixture, which consists of $5 \mu \mathrm{L} 10 \times$ buffer, $3 \mu \mathrm{L}$ of $25 \mathrm{mM} \mathrm{MgSO}_{4}, 5 \mu \mathrm{L}$ of $2 \mathrm{mM}$ dNTPs, $1.5 \mu \mathrm{L}$ of $10 \mu \mathrm{M}$ each forward (ek2-2000-5') and reverse (ek2-3') primers (Table 1 ), $5 \mu \mathrm{L}$ of $1 \mu \mathrm{g}$ DNA template, $1 \mu \mathrm{L}$ of $1 \mathrm{U} /$ $\mu \mathrm{L}$ KOD Hot Start DNA polymerase and $28 \mu \mathrm{L}$ of distilled water. The thermal cycle procedure was based on a threestep cycling procedure: Initiated with pre-denaturation at $95^{\circ} \mathrm{C}$ for $2 \mathrm{~min}$, followed by 25 cycles of denaturation at $95^{\circ} \mathrm{C}$ for $20 \mathrm{~s}$, primer annealing temperature for $10 \mathrm{~s}$ and extension at $70^{\circ} \mathrm{C}$ for $20 \mathrm{~s} / \mathrm{kb}$. Finally, the PCR process was ended by a final extension at $70^{\circ} \mathrm{C}$ for $5 \mathrm{~min}$. The PCR product of $e k 2$ promoter fragment was directionally cloned into pGL4.10 [luc2] vector at the XhoI/HindIII site 
to produce pGL4.10-ek2(-2000/+11). The ek2 promoter sequence was confirmed by DNA sequencing.

In order to map the important region for $e k 2$ promoter activity, 5' deletion constructs of $e k 2$ promoter, namely pGL4.10-ek2(-997/+11), pGL4.10-ek2(-741/+11) and pGL4.10-ek2(-304/+11) were amplified from the original pGL4.10-ek2(-2000/+11) construct with their respective forward primers (ek2-997-5', ek2-741-5' and $e k 2-304-5$ ', respectively) and a common reverse primer, $e k 2-3$ ' (Table 1). The PCR amplicons were directionally cloned into pGL4.10 [luc2] at the XhoI/HindIII sites. PGL4.10-ek2(-266/+11) was made by digesting pGL4.10$e k 2(-2000 /+11)$ with $S a c$ I. All constructs were verified by DNA sequencing. Nucleotides $-284,-287$ and -288 in the AP4 transcription factor binding site located at nucleotide -293 to -276 of $e k 2$ promoter were mutated by one-step PCR mutagenesis using $e k 2-$ mut(AP4) as forward primer and $e k 2-3^{\prime}$ as the reverse primer (Table 1, the mutated nucleotides are boldfaced in the ek2-mut(AP4) primer sequence) with pGL4.10-ek2(-304/+11) as the template. Mutated PCR amplicon was digested with $\mathrm{XhoI}$ and HindIII and inserted into linearized pGL4.10 plasmids. Sequence of the mutant construct pGL4.10-ek2-mut (AP4)(-304/+11) was verified by DNA sequencing.

\section{EK2 PROMOTER ACTIVITY ASSAY}

HepG2 cells $\left(1.5 \times 10^{4}\right.$ cells/well $)$ were transfected with $0.2 \mu \mathrm{g}$ of $e k 2$ promoter constructs and $0.0025 \mu \mathrm{g}$ of Renilla luciferase reporter vector pGL4.73 [hRluc/SV40] as internal control using Lipofectamine 2000 (Invitrogen, USA) according to the manufacturer's instructions. After $48 \mathrm{~h}$ of transfection, the cells were harvested and the promoter activity was assayed using Dual-Glo Luciferase Reporter Assay System (Promega). The firefly and Renilla luminescence signals were detected by GloMax 20/20 luminometer (Promega, USA) and the ratio of firefly to Renilla luminescence was translated into promoter activity presented as normalized luciferase activity. All experiments were performed in triplicate and the data were analyzed by student's t-test.

\section{RESULTS}

\section{IN SILICO CHARACTERIZATION OF EK2 PROMOTERS}

The $e k 2$ putative promoter sequence ( 5 ' upstream from the ATG translation start site) is shown in Figure 1. Two thousand base pairs located upstream of 5' region of $e k 2$ gene were analyzed for putative transcription factor binding elements with TFSEARCH and MatInspector 8.0. The location of predicted transcription factor binding elements in the promoter region of $e k 2$ is also presented in Figure 1.

Analysis showed that $e k 2$ promoter contains numerous putative transcription factor binding sites, including binding sites for Sp-family transcription factor, E26 transforming sequence (Ets)-related factor, GATA-related factor, sterol response element binding protein (SREBP), myeloid zinc finger 1 (MZF1), nuclear factor kappa B (NF- $\varkappa \mathrm{B})$, Ikaros (Ik)-2, signal transducers and activators of transcription (STAT)-family transcription factors, caudaltype homeodomain protein $(\mathrm{CdxA})$, cAMP responsive element binding protein (CREB), E1A-associated 300$\mathrm{kDa}$ protein (p300), paired related homeobox 2 (S8) and activating enhancer binding protein 4 (AP4). The analysis showed that $e k 2$ promoter is devoid of a recognizable consensus TATA box but contains a high number of $\mathrm{G}$ and $\mathrm{C}$ nucleotides, which is a typical characteristic for promoters lacking TATA box (Smale \& Kadonaga 2003). Sequence analysis also showed that $e k 2$ promoters contain a core promoter element, known as motif ten elements (MTE). Two MTEs (-138/-118 and -182/-162) were found in $e k 2$ promoter (Figure 1). The core promoter region for $e k 2$ was predicted based on the presence of MTE (Maston et al. 2006; Sandelin et al. 2007).

\section{LOCALIZATION AND IDENTIFICATION OF THE CIS-ACTING ELEMENTS THAT CONTRIBUTE TO BASAL EK2 PROMOTER ACTIVITY VIA 5'END DELETION ANALYSIS OF EK2 PROMOTER}

In order to determine the important cis-acting elements on the $e k 2$ promoter, two 5 ' end deletions constructs pGL4.10-

TABLE 1. Sequences of primers used in this study. Underlined bases indicate restriction enzyme recognition sites. Boldface indicates mutated bases. All primers were designed in this study

\begin{tabular}{|c|c|c|}
\hline Names & Sequence 5' to 3 ' & Description \\
\hline$e k 2-2000-5$ & CCG CTC GAG TGT AGC GCC AAG AGC CGG & $e k 2(2000)-X h o \mathrm{I}-5$ \\
\hline$e k 2-997-5$ & 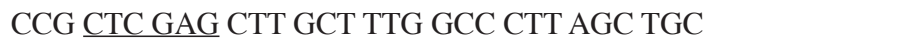 & $e k 2(997)-X h o I-5$ \\
\hline$e k 2-741-5$ & 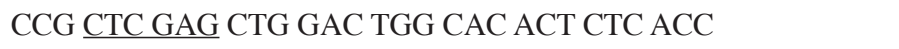 & $e k 2(741)-X h o I-5$ \\
\hline$e k 2-304-5$ & 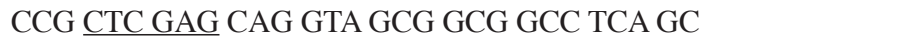 & $e k 2(304)-X h o I-5$ \\
\hline$e k 2-3$ & CCC $\underline{A A G ~ C T T ~ G G C ~ A C A ~ G C C ~ A T T ~ C C C ~ A G C ~ A G C ~}$ & ek2-HindIII-3' \\
\hline pGL4.10-3' & GGG CGT AGC GCT TCA TGG C & pGL4.10-3' reverse primer \\
\hline$e k 2$-mut (AP4) & 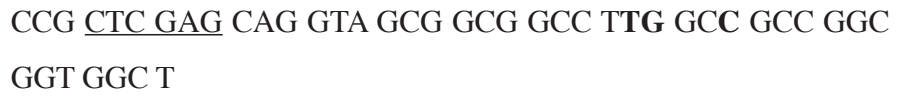 & AP4 site mutagenesis primer \\
\hline
\end{tabular}




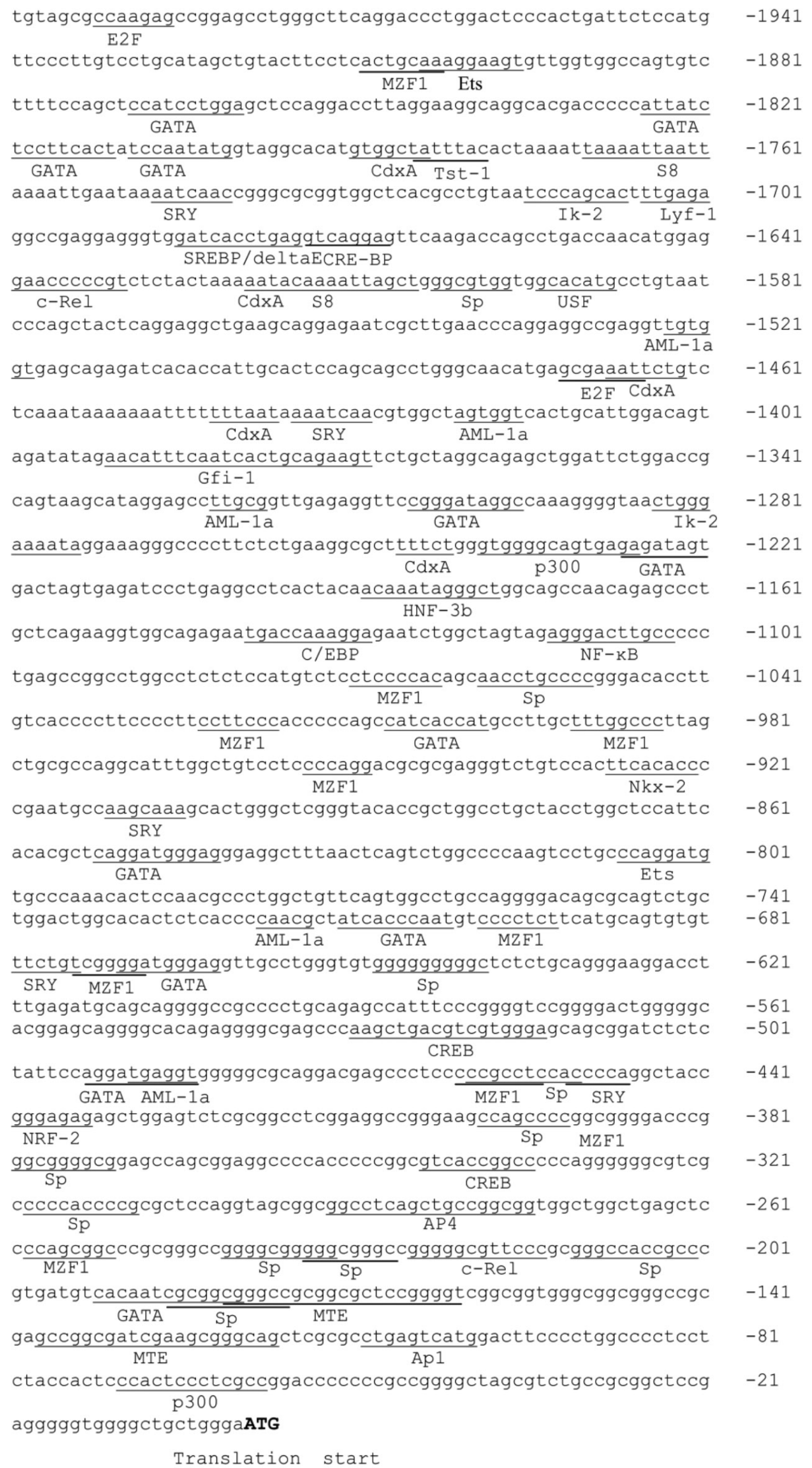

FIGURE 1. Predicted transcription factor binding sites on $e k 2$ promoter. The transcription factor binding elements are indicated by underlined sequence. The numbers shown on the right indicate the number of bases from the translation start site (ATG). The ATG start codon is shown in boldface and assigned as +1 and nucleotides upstream of +1 are denoted as negative numbers 
ek2 $(-997 /+11)$ and pGL4.10-ek2 (-266/+11) were generated. An initial analysis of $e k 2$ promoter activity was performed with these three promoter constructs in HepG2 cells. As shown in Figure 2, the $-2000 /+11$ ek2 promoter was functional in HepG2 cells, where its activity was about $900 \%$ higher than the empty pGL4.10 [luc2] vector. The results justified the use of $\mathrm{HepG} 2$ cell line for $e k 2$ promoter analysis in this study. As shown in Figure 2, the minimal ek2 promoter fragment, -266/+11 showed the highest promoter activity in HepG2 cells. A significant increase of promoter activity by $383 \%$ compared to pGL4.10-ek2 $(-997 /+11)$ construct was observed when the promoter fragment was truncated from -997 to -266 (Figure 2). This result showed that important negative regulatory binding sites could be located in the region between -997 and -266. The maximal promoter activity exhibited by the $-266 /+11$ $e k 2$ promoter fragment suggested that the basal promoter region is mainly located within the 266 bp promoter region upstream of the ATG translation start site.
Another series of deletion constructs were made to narrow the region of interest between -997 and -266 to identify the potential inhibitory binding site on the $e k 2$ promoter (Figure 3). A putative AP4 site (-293/-276) located in the region between -304 and -266 of $e k 2$ promoter was identified as the one that significantly repressed the promoter activity (Figure 3 ). The promoter activity increased significantly after the removal of AP4 binding site as seen in [pGL4.10-ek2(-266/+11)] construct.

\section{PROMOTER ACTIVITY OF pGL4.10-EK2(-30 4/+11) AND pGL4.10-EK2-MUT (AP4)(-304/+11)}

In order to study and verify the importance of AP4 element in the ek2 promoter, the AP4 binding site was mutated at the E-box motif in the pGL4.10-ek2 (-304/+11) construct. As shown in Figure 4, mutation of AP4 binding site resulted in almost $60 \%$ increase of promoter activity. The results show that AP4 binding site is a repressive element in $e k 2$ promoter.

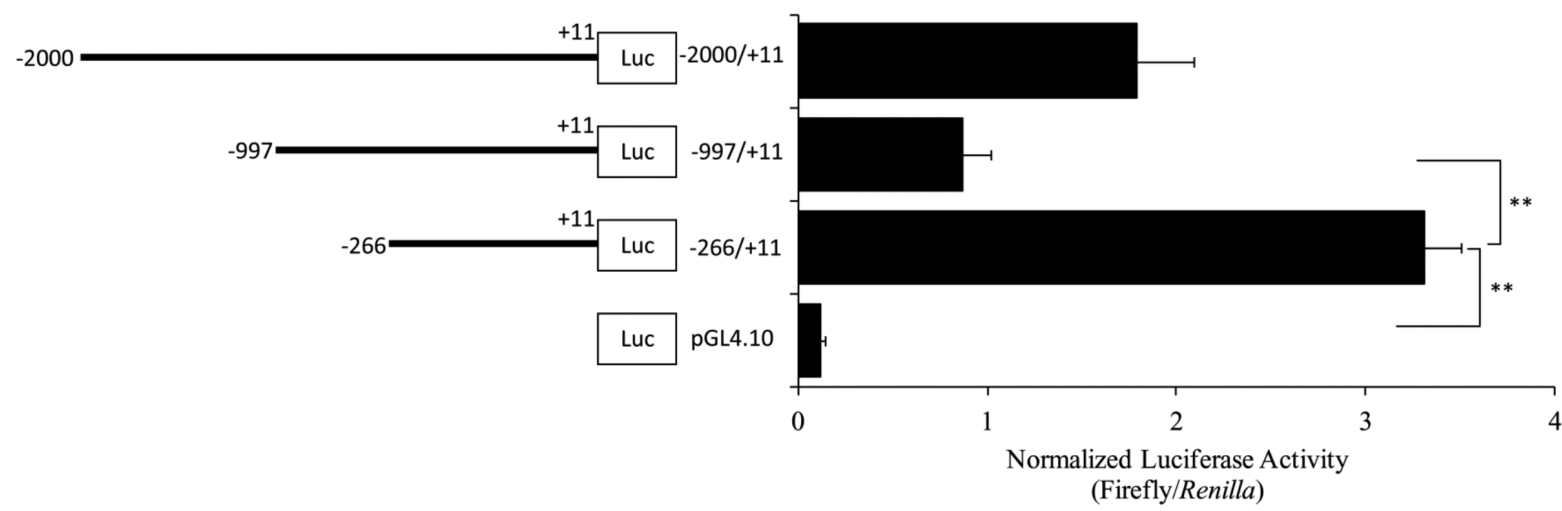

FIGURE 2. Deletion analysis of the ek2 promoter in HepG2 cells. Left panel shows the schematic structures of the 5' step-wise deletion constructs used to test the functional activity of $e k 2$ promoter. Each bar represents the mean \pm SEM of triplicate samples from three independent experiments. Statistical analysis was performed using Student's t-test. $(* * p<0.01)$

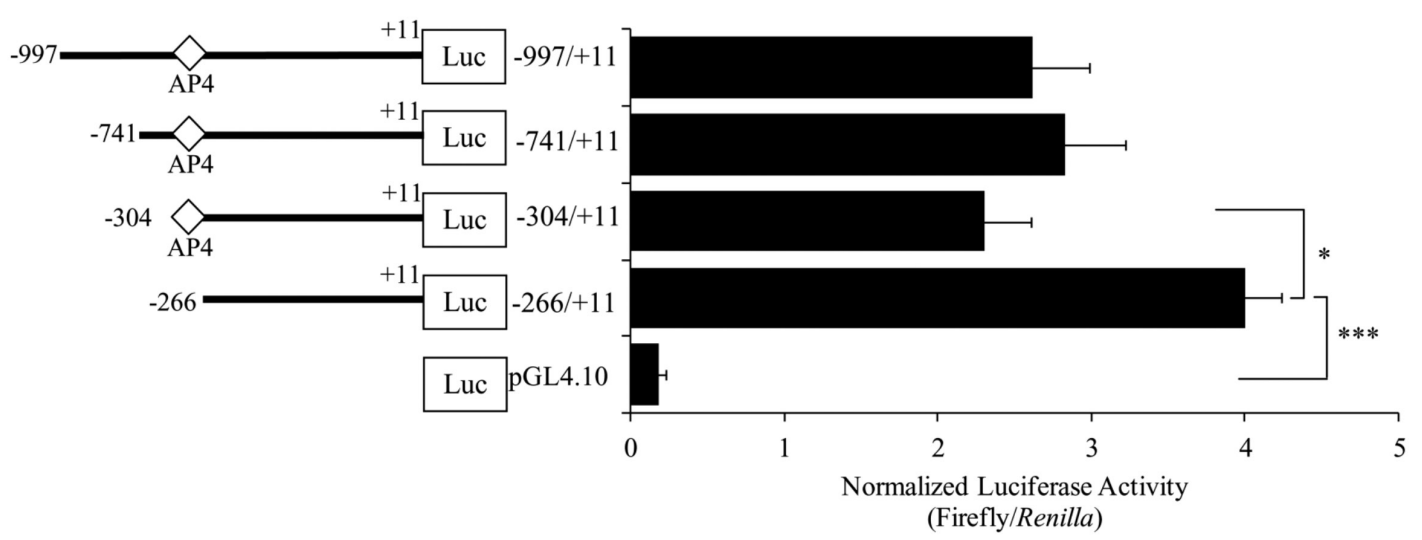

FIGURE 3. Second series of deletion analysis of ek2 promoter in HepG2 cells. Left panel shows the schematic structures of the 5' step-wise deletion constructs used to test the functional activity of ek2 promoter between -997 and -266. Binding site for AP4 transcription factor is indicated with diamond. Each bar represents the mean \pm SEM of triplicate samples from three independent experiments. Statistical analysis was performed using Student's $t$-test $(* p<0.05$; *** $p<0.001)$ 


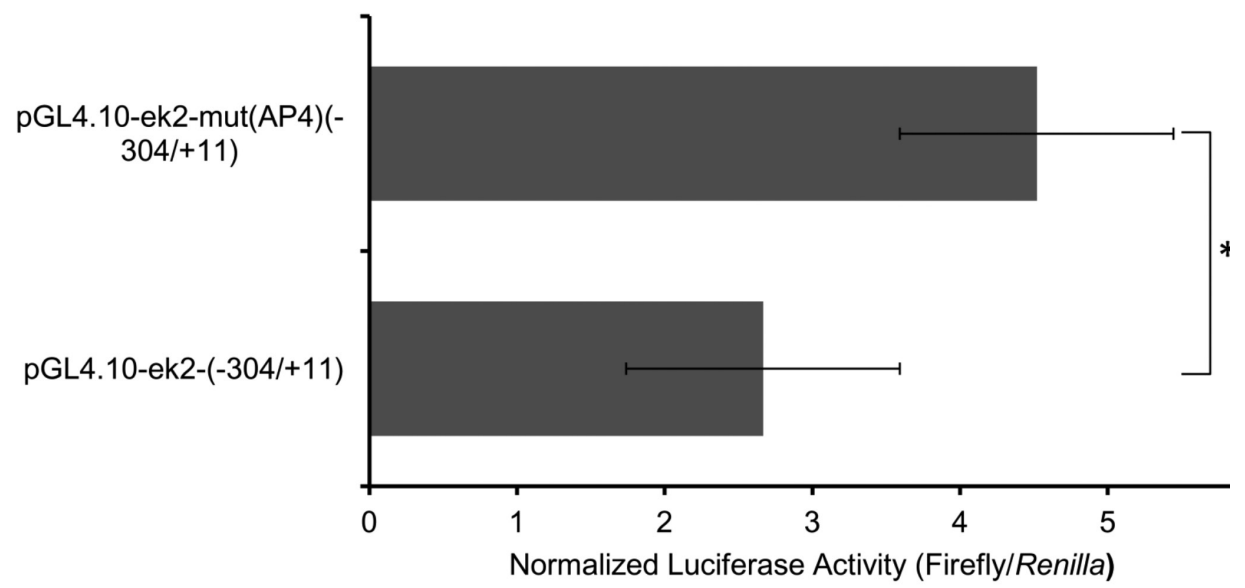

FIGURE 4. Promoter activity of wild type pGL4.10-ek2(-304/+11) and mutant pGL4.10-ek2-mut(AP4)(-304/+11). $\left({ }^{*} p<0.05\right)$

\section{DISCUSSION}

In this work, our sequence analysis showed that unlike common eukaryotic gene promoters, which have consensus TATA box sequence in the transcription initiation site, $e k 2$ promoter is a typical TATA-less promoter. Apart from the absence of TATA box, $e k 2$ promoter also has high guanine (G) and cytosine (C) content. TATA-less promoters do not have unique starting point due to the absence of anchoring effect of the TATA box. Slippery interaction between the basal transcription machinery and the DNA may cause transcriptional initiation to occur from widely distributed locations (Suzuki et al. 2001). Since there is no direct method to define the exact promoter sequence responsible for regulating $e k 2$ gene expression, approximately $2 \mathrm{~kb}$ upstream of the ATG translation start site of $e k 2$ gene was isolated and analyzed. According to Cooper et al. (2006), promoter sequence of about 300 to $50 \mathrm{bp}$ upstream from transcription start site (TSS) positively contributes to the basal promoter activity of a gene while putative negative regulatory elements are usually located at about 1000 to $500 \mathrm{bp}$ upstream of TSS. Therefore, it was assumed in this study that the 2000 bp upstream region from the translation start site would cover the important regulating regions in $e k 2$ promoter.

The activities of $e k 2$ promoter constructs were determined by firefly luciferase and Renilla luciferase dual reporter system. Firefly (Photinus pyralis) luciferase reporter technology offers good sensitivity, dynamic range, versatility and ease of use for investigating gene regulation in cultured cells. The method is also preferred for the analysis of weak promoter or problem with low transfection efficiency in certain mammalian cell lines (de Wet et al. 1987; Ow et al. 1986). Firefly luciferase encoded by $l u c 2$ gene in pGL4.10 vector generates luminescence in the green-yellow region $(550-570 \mathrm{~nm})$ from beetle luciferin in the presence of ATP, magnesium and oxygen (de Wet et al. 1987; Thorne et al. 2010). Renilla (Renilla reniformis) on the other hand catalyzes the oxidation of coelenterazine to produce coelenteramide, carbon dioxide and emits blue light of $480 \mathrm{~nm}$ (Shifera \& Hardin 2010). Renilla luciferase uses a different substrate from firefly luciferase and its independence of ATP and magnesium usage making it suitable as the internal control in the dual reporter system.

The significant increase of $e k 2$ promoter activity after mutation of the E-box motif in the AP4 binding site implies the ablation of a repressive element on $e k 2$ promoter. This strongly suggests the possible repression role of AP4 transcription factor in the regulation of $e k 2$ gene expression. It has been reported that AP4 binds to the E-box motif on the phytanoyl-CoA alpha-hydroxylase-associated protein 1 (PAHX-AP1) gene promoter, together with geminin, a complex is formed to work as a transcriptional repressor and corepressor, respectively, for exogenous regulation of PAHX-AP1 promoter (Kim et al. 2006). On the other hand, a different AP4 repression mechanism has also been reported where AP4 cooperates with other factors to synergistically repress cluster of differentiation 4 (CD4) expressions (Egawa \& Littman 2011). These examples illustrate the repressive role of AP4 in various promoters, even though the repression mechanism and the degree of repression for each gene may differ. The present study reports the first characterization of human $e k 2$ gene promoter and showed that the putative AP4 binding site located between - 293 and -276 was a repressive $c i s$-acting element. The AP4 binding site might play an important role in carcinogenesis since AP4 upregulation has been associated with poor prognosis of carcinoma cells (Liu et al. 2012).

\section{CONCLUSION}

This study shows that AP4 transcription factor binding site acts as a repressive element in the regulation of $e k 2$ expression, although further studies are still needed to determine the repression mechanism of $e k 2$ promoter by AP4. Understanding the involvement of AP4 in the regulation of $e k 2$ gene expression provides insight into the regulation of PtdEtn synthesis and embryonic development. 


\section{ACKNOWLEDGEMENTS}

This work is supported by Universiti Sains Malaysia Research University grant (1001/PPSK/812179) and Fundamental Research Grant Scheme, Ministry of Higher Education (MOHE), Malaysia (203/PPSK/6171171). Zhi Hui Teh is supported by the Universiti Sains Malaysia Fellowship Scheme. We would like to thank the laboratory staff of School of Health Sciences for their technical assistance.

\section{REFERENCES}

Bleijerveld, O.B., Brouwers, J.F., Vaandrager, A.B., Helms, J.B. \& Houweling, M. 2007. The CDP-ethanolamine pathway and phosphatidylserine decarboxylation generate different phosphatidylethanolamine molecular species. Journal of Biological Chemistry 282: 28362-28372.

Chua, S.L., Khoo, B.Y., See Too, W.C. \& Few, L.L. 2015. Expression profiling of choline and ethanolamine kinases in MCF7, HCT116 and HepG2 cells, and the transcriptional regulation by epigenetic modification. Molecular Medicine Reports 11: 611-618.

Cooper, S.J., Trinklein, N.D., Anton, E.D., Nguyen, L. \& Myers, R.M. 2006. Comprehensive analysis of transcriptional promoter structure and function in $1 \%$ of the human genome. Genome Research 16: 1-10.

de Wet, J.R., Wood, K., DeLuca, M., Helinski, D.R. \& Subramani, S. 1987. Firefly luciferase gene: Structure and expression in mammalian cells. Molecular and Cellular Biology 7: $725-737$

Egawa, T. \& Littman, D.R. 2011. Transcription factor AP4 modulates reversible and epigenetic silencing of the $\mathrm{Cd} 4$ gene. Proceedings of the National Academy of Sciences 108: 14873-14878.

Heinemeyer, T., Wingender, E., Reuter, I., Hermjakob, H., Kel, A.E., Kel, O.V., Ignatieva, E.V., Ananko, E.A., Podkolodnaya, O.A., Kolpakov, F.A., Podkolodny, N.L. \& Kolchanov, N.A. 1998. Databases on transcriptional regulation: TRANSFAC, TRRD and COMPEL. Nucleic Acids Research 26: 362-367.

Hurley, T.M., McClive, P.J., Sarraj, M.A. \& Sinclair, A.H. 2004. Eki2 is upregulated specifically in the testis during mouse sex determination. Gene Expression Patterns 4: 135-140.

Kent, W.J. 2002. BLAT--the BLAST-like alignment tool. Genome Research 12: 656-664.

Kim, M.Y., Jeong, B.C., Lee, J.H., Kee, H.J., Kook, H., Kim, N.S., Kim, Y.H., Kim, J.K., Ahn, K.Y. \& Kim, K.K. 2006. A repressor complex, AP4 transcription factor and geminin, negatively regulates expression of target genes in nonneuronal cells. Proceedings of the National Academy of Sciences 103: 13074-13079.

Kiss, Z. 1999. Regulation of mitogenesis by water-soluble phospholipid intermediates. Cell Signaling 11: 149-57.

Kuan, C.S., See Too, W.C. \& Few, L.L. 2016. Sp1 and Sp3 are the transcription activators of human $e k 1$ promoter in TSA-treated human colon carcinoma cells. PLOS ONE 11: e0147886. doi:10.1371/journal.pone.0147886.

Liu, X., Bo, Z., Yan, G., Lei, W., Wu, C., Qi, L., Lin, Y., Tao, K., Wang, G. \& Chen, J. 2012. The overexpression of AP-4 as a prognostic indicator for gastric carcinoma. Medical Oncology 29: 871-877.

Lykidis, A., Wang, J., Karim, M.A. \& Jackowski, S. 2001. Overexpression of a mammalian ethanolamine-specific kinase accelerates the CDP-ethanolamine pathway. Journal of Biological Chemistry 276: 2174-2179.

Maston, G.A., Evans, S.K. \& Green, M.R. 2006. Transcriptional regulatory elements in the human genome. Annual Review of Genomics and Human Genetics 7: 29-59.

Ow, D.W., de Wet, J.R., Helinski, D.R., Howell, S.H., Wood, K.V. \& Deluca, M. 1986. Transient and stable expression of the firefly luciferase gene in plant cells and transgenic plants. Science 234: 856-859.

Quandt, K., Frech, K., Karas, H., Wingender, E. \& Werner, T. 1995. MatInd and MatInspector: New fast and versatile tools for detection of consensus matches in nucleotide sequence data. Nucleic Acids Research 23: 4878-4884.

Sandelin, A., Carninci, P., Lenhard, B., Ponjavic, J., Hayashizaki, Y. \& Hume, D.A. 2007. Mammalian RNA polymerase II core promoters: Insights from genome-wide studies. Nature Reviews Genetics 8: 424-436.

Shifera, A.S. \& Hardin, J.A. 2010. Factors modulating expression of Renilla luciferase from control plasmids used in luciferase reporter gene assays. Analytical biochemistry 396: 167-172.

Smale, S.T. \& Kadonaga, J.T. 2003. The RNA polymerase II core promoter. Annual Review of Biochemistry 72: 449-479.

Spanner, S. \& Ansell, G.B. 1978. Choline kinase and ethanolamine kinase activity in the cytosol of nerve endings from rat forebrain. Biochemical Journal 178: 753-760.

Suzuki, Y., Taira, H., Tsunoda, T., Mizushima-Sugano, J., Sese, J., Hata, H., Ota, T., Isogai, T., Tanaka, T. \& Morishita, S. 2001. Diverse transcriptional initiation revealed by fine, large-scale mapping of mRNA start sites. EMBO Reports 2: 388-393.

Thorne, N., Inglese, J. \& Auld, D.S. 2010. Illuminating insights into firefly luciferase and other bioluminescent reporters used in chemical biology. Chemistry \& Biology 17: 646-657.

Tian, Y., Jackson, P., Gunter, C., Wang, J., Rock, C.O. \& Jackowski, S. 2006. Placental thrombosis and spontaneous fetal death in mice deficient in ethanolamine kinase 2. Journal of Biological Chemistry 281: 28438-28449.

Vance, J.E. 2008. Thematic review series: Glycerolipids. phosphatidylserine and phosphatidylethanolamine in mammalian cells: Two metabolically related aminophospholipids. Journal of Lipid Research 49: 13771387.

Walkey, C.J., Yu, L., Agellon, L.B. \& Vance, D.E. 1998. Biochemical and evolutionary significance of phospholipid methylation. Journal of Biological Chemistry 273: $27043-$ 27046.

School of Health Sciences, Health Campus

Universiti Sains Malaysia

16150 Kubang Kerian, Kelantan Darul Naim

Malaysia

*Corresponding author; email: fewling@usm.my

Received: 8 September 2016

Accepted: 6 March 2017 